Primljen / Received: 30.6.2017. Ispravljen / Corrected: 16.4.2018.

Prihvaćen / Accepted: 30.5.2018. Dostupno online / Available online: 10.12.2018.

\section{Effects of diaphragm flexibility on seismic response of asymmetric-plan buildings}

Authors:

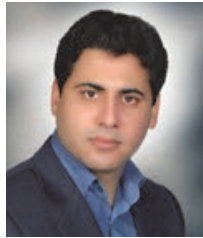

Hamed Eivani, MSc. CE

Islamic Azad University, Tehran, Iran

Department of Civil Engineering

Science and Research Branch

H_aivani@yahoo.com

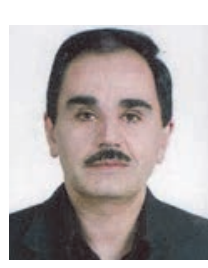

Assoc.Prof. Abdolreza S. Moghadam, PhD. CE International Institute of Earthquake Engineering and Seismology - IIEES

Tehran, Iran

moghadam@iiees.ac.ir

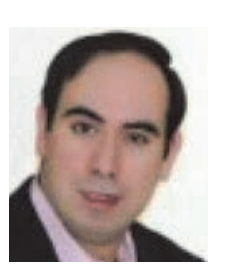

Assist.Prof. Armin Aziminejad, PhD. CE Islamic Azad University, Tehran, Iran Department of Civil Engineering armin.aziminejad@gmail.com

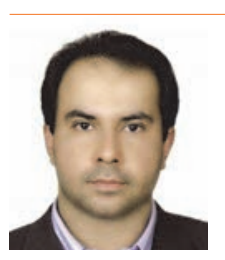

Assist.Prof. Masoud Nekooei, PhD. CE Islamic Azad University, Tehran, Iran Department of Civil Engineering msnekooei@gmail.com
Hamed Eivani, Abdolreza S. Moghadam, Armin Aziminejad, Masoud Nekooei

Effects of diaphragm flexibility on seismic response of asymmetric-plan buildings

The effects of diaphragm flexibility on seismic response of asymmetric-plan buildings are investigated in this paper. The results show that the diaphragm flexibility could induce different effects depending on the asymmetric system characteristics, selected element, level of structure yield, and degree of diaphragm flexibility. When the structure behaves in elastic range, central walls exhibit a significant increase in response, and the situation can further be aggravated by asymmetricity in system. Also, all walls of the structure experience a significant increase in response in nonlinear range, which cannot be ignored.

\author{
Key words: \\ diaphragm flexibility, asymmetric-plan structure, seismic response, nonlinear analysis
}

Prethodno priopćenje

Hamed Eivani, Abdolreza S. Moghadam, Armin Aziminejad, Masoud Nekooei

\section{Učinci popuštanja stropne ploče na seizmički odziv tlocrtno nesimetrične konstrukcije}

U ovom se radu istražuje utjecaj popuštanja stropne ploče na seizmički odziv konstrukcija nesimetrična tlocrta. Analizom rezultata možemo uočiti različite posljedice popuštanja, što ovisi o svojstvima nesimetričnog sustava, razmatranom elementu, razini popuštanja ploče i konstrukcije. Za model u elastičnom području, kod unutarnjih se zidova uočava značajan porast odziva, uz moguće pogoršanje zbog nesimetričnih svojstava. Osim toga, kod svih je zidova zamijećen značajan porast odziva u nelinearnom području, koji se ne smije zanemariti.

Ključne riječi:

popuštanje ploče, konstrukcija nesimetrična tlocrta, seizmički odziv, nelinearna analiza

Vorherige Mitteilung

Hamed Eivani, Abdolreza S. Moghadam, Armin Aziminejad, Masoud Nekooei

\section{Auswirkungen des Absenkens der Deckenplatte auf die seismische Reaktion der asymmetrischen Grundrisskonstruktion}

In dieser Abhandlung wird der Einfluss des Absenkens der Deckenplatte auf die seismische Reaktion der asymmetrischen Grundrisskonstruktion untersucht. Durch die Analyse der Ergebnisse können wir unterschiedliche Folgen des Absenkens feststellen, was von den Eigenschaften des asymmetrischen Systems, vom betrachteten Element, vom Niveau des Absenkens der Platte und der Konstruktion abhängt. Für das Modell im elastischen Bereich wird eine deutliche Steigerung der Reaktion bei den Innenwänden festgestellt, mit einer möglichen Verschlechterung aufgrund der asymmetrischen Eigenschaften. Darüber hinaus wurde bei allen Wänden eine erhebliche Steigerung der Reaktion im nicht linearen Bereich festgestellt, die nicht vernachlässigt werden sollte.

Absenken der Platte, asymmetrische Grundrisskonstruktion, seismische Reaktion, nicht lineare Analyse 


\section{Introduction}

In most previous studies on asymmetric-plan buildings, fully rigid diaphragm has been considered as a basic assumption. As a result of this assumption, distribution of inertial forces between lateral load-resisting elements (LLREs) of a structure is only dependent on its mass, stiffness and strength distribution. However, in many cases, fully rigid diaphragm assumption is not consistent with reality, and seismic diaphragms, especially in asymmetric-plan structures, can exhibit various degrees of flexibility [1-4].

Diaphragm flexibility can change the distribution of inertia forces between the LLREs and therefore can be the source of the difference between the results of the numerical analysis and the actual behaviour of the structure during the earthquakes. As an example of extreme case, for structures with completely flexible diaphragms, distribution of inertial forces between the LLREs is determined only by tributary area, so torsional response is not considered in these structures.

Due to the simultaneously effects of both diaphragm flexibility and structural asymmetry on distribution of inertial forces between LLREs, evaluation of combined effects of these two factors on structure response is one of main objectives of this research, which has been considered to a lesser extent in previous studies. The effects of diaphragm flexibility on seismic response of asymmetric structures are studied in this paper using the dynamic time history analysis. A wide range of diaphragm flexibilities, from fully rigid to absolutely flexible, is considered. The uncoupled natural period, stiffness eccentricity and uncoupled torsional to lateral frequency ratio, are the most significant factors of asymmetric structures considered in numerical modelling. Ratios of different responses of structures with flexible diaphragms to those in similar structures with rigid diaphragms are calculated to determine the effect of flexibility on structural behaviour.

\subsection{Literature review}

Although studies of asymmetric-plan structures date back to about seven decades ago, in most cases they assume, as a basic assumption, full rigidity of seismic diaphragms. However, recent research $[2,3]$ has clearly shown that the assumption of full rigidity of diaphragms is not realistic in many structures. These findings indicate that, depending on the LLREs system, plan aspect ratio, floor type, and design methodology, a structure can exhibit different degrees of diaphragm flexibility. Generally, most previous studies analyse the effects of diaphragm flexibility on symmetric structures [5-7]. These studies show that diaphragm flexibility has greater effects on seismic response of low-rise structures with stiffer LLREs [8], lower storey height [6], lower number of spans $[5,8]$, and larger plan aspect ratios $[5,6]$. Moon and Lee [9] showed that the flexible diaphragm increases fundamental natural period of structures and also modifies vibrational modes. They concluded that, although increasing the diaphragm flexibility could reduce the total base shear of entire structure, it leads however to increasing force absorption of internal LLREs.
Tremblay and Stiemer [10] found that rigid diaphragm assumption has led to underestimation of deformations, forces, and maximum drift values in diaphragm and ductility demand of the LLREs. Based on a parametric study on symmetric reinforced masonry structures, Kim and White [11] have established that the maximum in-plane deformation of walls occurs when the diaphragm exhibits a semi-rigid behaviour.

As mentioned above, the evaluation of seismic response of asymmetric-plan structures with flexible diaphragms is a topic that has been less considered in previous studies. Some studies have shown that the torsional response of structures reduces significantly when the diaphragm flexibility is increased [1, 12-14]. Tena-Colunga and Abrams [14] pointed that, although torsional response decreases with an increase in diaphragm flexibility, the design of asymmetric-plan structures based on rigid diaphragm assumption is non-conservative. Nakamura et al. [15] reported that characteristics of transverse walls, except in very stiff diaphragms cases, do not have a considerable influence on seismic response of asymmetric-plan structures with flexible diaphragm. In a comprehensive parametric study, Eivani et al. [16] evaluated proper configurations of the centres (mass, stiffness and strength) in asymmetric-plan structures with flexible diaphragms. They concluded that proper configurations of centres in these structures greatly resemble such configurations in similar structures with rigid diaphragm.

\subsection{Flexibility index of diaphragms}

As shown in Figure 1, the static flexibility ratio $\gamma_{P L_{i}}$ is defined as the ratio of the maximum diaphragm deflection $\Delta_{\mathrm{PLH}_{-}}$to average drift of adjoining LLRES $\Delta_{B N E_{-} i}$ under uniform distributed lateral load along the diaphragm (DPH) [17].

$$
\gamma_{P L_{-} i}=\frac{\Delta_{P L H_{-} i}}{\Delta_{B N E_{-} i}}
$$

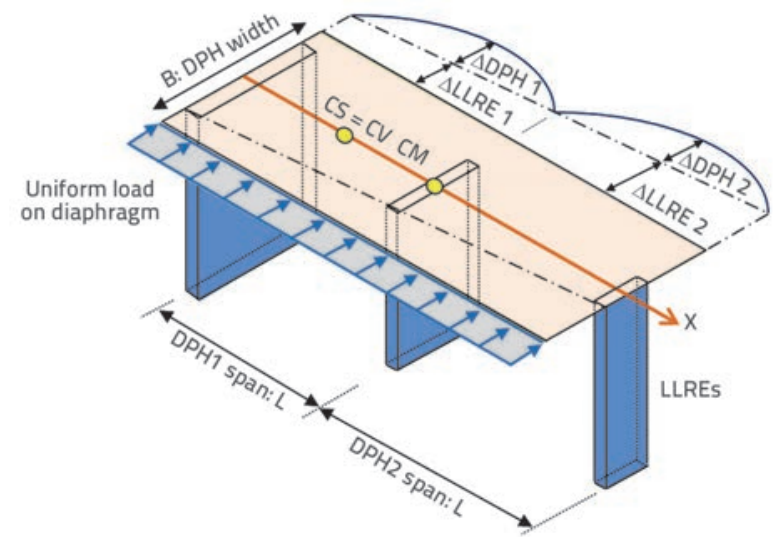

Figure 1. Typical behaviour of diaphragms in an asymmetric-plan structure

As clearly presented in Figure 1, in asymmetric-plan structures, each structural span may have a different static flexibility ratio $\gamma_{P_{-} ;}$Since the main purpose of this paper is to investigate the 
effects of diaphragm flexibility on overall asymmetric behaviour of structures, it is essential to express a global diaphragm flexibility index for multi-span asymmetric-plan structures.

In a similar research, Farrow and Fleischman [2] introduced a structure flexibility index for multi-storey structures. They considered the static flexibility ratio at mid-height of the structure as the global diaphragm flexibility index that approximately equals the average value of diaphragm flexibility ratios for the entire structure. In a similar way, a global diaphragm flexibility index $\gamma_{s}$ for multi-span asymmetric-plan structures is defined as an average of all spans static flexibility ratio, Eq (2):

$\gamma_{\mathrm{s}}=$ Average $\left(\gamma_{\mathrm{PL}_{-} 1}, \gamma_{\mathrm{PL}_{2}{ }^{2}}, \ldots\right)$

\section{Structural systems and methodology of analysis}

\subsection{Buildings with rigid diaphragms}

Symmetric and asymmetric-plan single-storey systems with rigid diaphragm and same plan-dimensions were considered in the first step (Figure 2a). Models were exposed to unidirectional seismic excitations. LLREs can be representatives of shear walls and/or frame components. As shown in Figure 2b, elements stiffness was
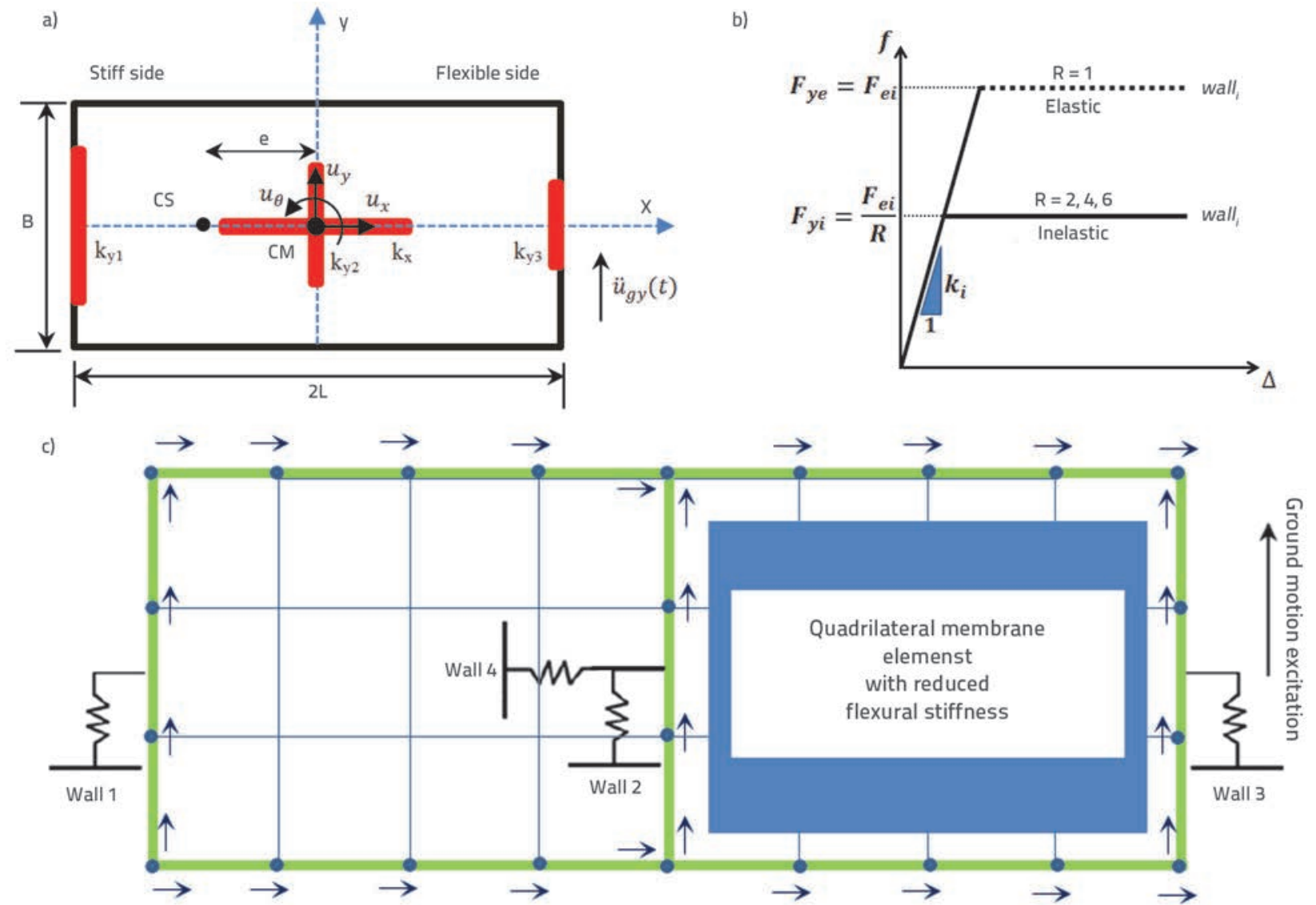

orizontal DOFs rigidity link

Truss elements (Axial stiffness of primary beams)

Figure 2. Typical analysed building: a) plan view; b) considered force-displacement relationship for a sample LLRE; c) numerical model

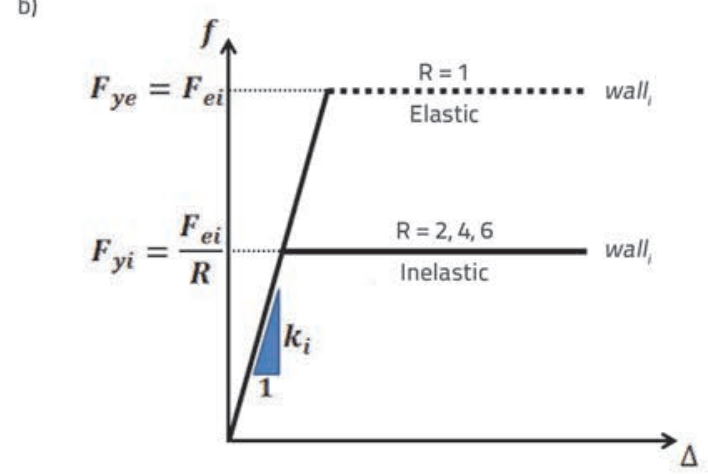

considered to be independent of their strength. It can be noted that, although current design procedures [17] have been developed based on this assumption, some studies $[18,19]$ show that it does have limitations in some LLREs such as shear walls.

Based on previous studies [20], the force-displacement relationship of LLREs was considered as a bi-linear relationship. The post-yield stiffness was considered zero for all walls. It is important to observe that, based on findings of Tso and Myslimaj [21], the results for a degrading hysteretic model are basically similar to the results for an elastoplastic model. Structures modelling and analyses have been done using the OpenSees [22]. Being based on the principles of many seismic design codes $[17,23]$, seismic diaphragms must be designed in such a way that they behave in an elastic range, i.e. an elastic behaviour is intended for the diaphragms. Quadrilateral membrane elements with isotropic elastic behaviour have been used for diaphragms modelling. The type of floor system, and also the direction of secondary beams of the floor, were not considered explicitly. The mesh sensitivity analysis was performed and approved [16]. In diaphragms modelling, to avoid the concentration of deformations in the LLREs to diaphragm connection point, especially in flexible cases, the axial stiffness of primary beams was calculated based on initial design (under gravity and seismic

b)

. 


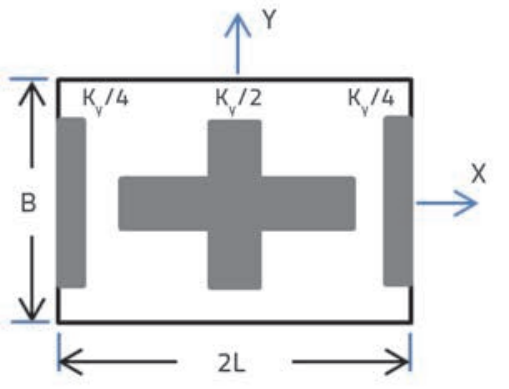

$\Omega=1,22$

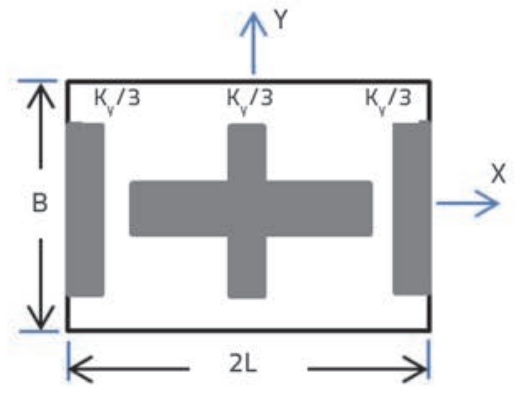

$\Omega=1,41$

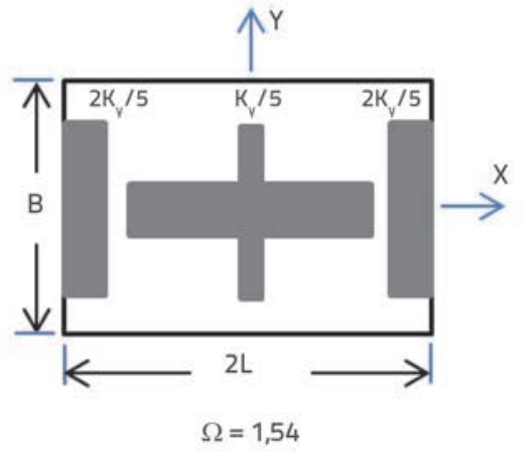

Figure 3. $\Omega$ for three considered distributions of stiffness in symmetric structures

loads) of structures and was modelled using truss elements (Figure 2c). Rayleigh damping proportional to the mass and stiffness matrices was used with the damping ratio of $5 \%$ of critical damping for modes 1 and 3. More details can be found in Eivani Ph.D. thesis [16].

$T$ (Uncoupled natural period in $y$-direction), $e$ (stiffness eccentricity in $\mathrm{x}$-direction), and $\Omega$ (ratio of torsional to lateral frequency in $y$-direction), are the main parameters that affect seismic response of asymmetric structures with flexible diaphragms. They were investigated as follow:

- Three values of uncoupled lateral period Tnamely $0.1,0.5$, and 1.0 $\mathrm{s}$, were considered. These values are representative of structures with the short, medium and long periods, respectively.

- The systems with none, small, medium and large eccentricities (e/2L $=0 \%, 5 \%, 10 \%, 20 \%)$ were considered. Eccentricities values are presented in all diagrams in an abbreviated form as follows.

- Three different values of uncoupled torsional to lateral period ratio $\Omega$, namely 1.22, 1.41, and 1.54, were employed (Figure 3). Given that $\Omega>1$ in the considered models, their responses were predominantly in transitional mode (torsionally stiff systems). The mentioned models are representative of a wide range of asymmetric buildings [19].

\subsection{Diaphragm flexibility incorporation}

The global diaphragm flexibility index for structures varied from fully rigid $\left(\gamma_{s}=0\right)$ to quite flexible $\left(\gamma_{s}=5,0\right)$. It should be noted that the aspect ratio, span length and material of diaphragms were considered to be the same in both spans of structures. So, the difference in stiffness of adjacent LLREs was the only source of difference in the flexibility ratio of diaphragms $\gamma_{P L_{-} ;}$The range of variables in parametric study is presented in Table 1.

\subsection{Methodology}

A step by step method, aimed at investigating the effects of both asymmetric structure parameters $(T, e, \Omega)$ and diaphragm flexibility $\left(\gamma_{s}\right)$ on the seismic response of structures, was used as follow:

Step A: Design of structures with rigid diaphragm to achieve predetermined values of $T$, $e$ and $\Omega$ presented in Table 1 .

1. Considering each of uncoupled natural periods from Table 1 $\left(T_{\text {rigo }}\right)$ and assuming a realistic amount of the total mass of rigid diaphragm $(M)$, the overall stiffness of lateral elements of a structure $\left(K_{y 0}=\sum k_{y i}\right)$ was calculated using Eq. (3):

$T=2 \pi \sqrt{\frac{M}{K_{y 0}}} \Rightarrow K_{y 0}=\frac{4 \pi^{2} M}{T^{2}}, K_{x 0}=K_{y 0}$

2. Assuming predetermined values of $T$, e and $\Omega$, the stiffness of three lateral walls in $y$-direction was calculated by solving the following three equations simultaneously (Eq (4)):

$$
\left[\begin{array}{c}
k_{y 1}+k_{y 2}+k_{y 3}=K_{y 0} \\
k_{y 1}\left(L-e_{0}\right)-k_{y 2}\left(e_{0}\right)-k_{y 3}\left(L+e_{0}\right)=0 \\
k_{y 1}\left(L-e_{0}\right)^{2}+k_{y 2}\left(e_{0}\right)^{2}+k_{y 3}\left(L+e_{0}\right)^{2}=K_{y 0} \Omega^{2} r_{m}^{2}
\end{array}\right] \Rightarrow k_{y 1}, k_{y 2}, k_{y 3}
$$

where $r_{m}$ is the radius of gyration of the rigid diaphragm.

Step B: Time history dynamic analysis of structures using the suite of 20 SAC (SEAOC-ATC-CUREE) LA records, and with probabilities of exceedance of $10 \%$ in 50 years, according to standard 2800 of Iran [23] was done, (Figure 4).

Step C: The diaphragm flexibility increased to achieve certain levels of flexibility index $\left(\gamma_{s}\right)$, as specified in Table 1.

Table 1. Domain of structures considered in parametric study

\begin{tabular}{|l|c|c|}
\hline \multirow{2}{*}{ Asymmetric structures parameters } & Uncoupled natural period $(\mathrm{T})$ & $0.1 \mathrm{~s}, 0.5 \mathrm{~s}, 1.0 \mathrm{~s}$ \\
\cline { 2 - 3 } & Stiffness eccentricity $(\mathrm{e} / 2 \mathrm{~L})$ & $0 \%, 5 \%, 10 \%, 20 \%$ \\
\cline { 2 - 3 } & Uncoupled torsional to lateral period ratio $(\Omega)$ & $1.22,1.41,1.54$ \\
\hline \multicolumn{2}{|c|}{ Diaphragm flexibility index of structure $\left(\gamma_{\mathrm{s}}\right)$} & $0.0,1.0,2.0,3.0,4.0,5.0$ \\
\hline
\end{tabular}



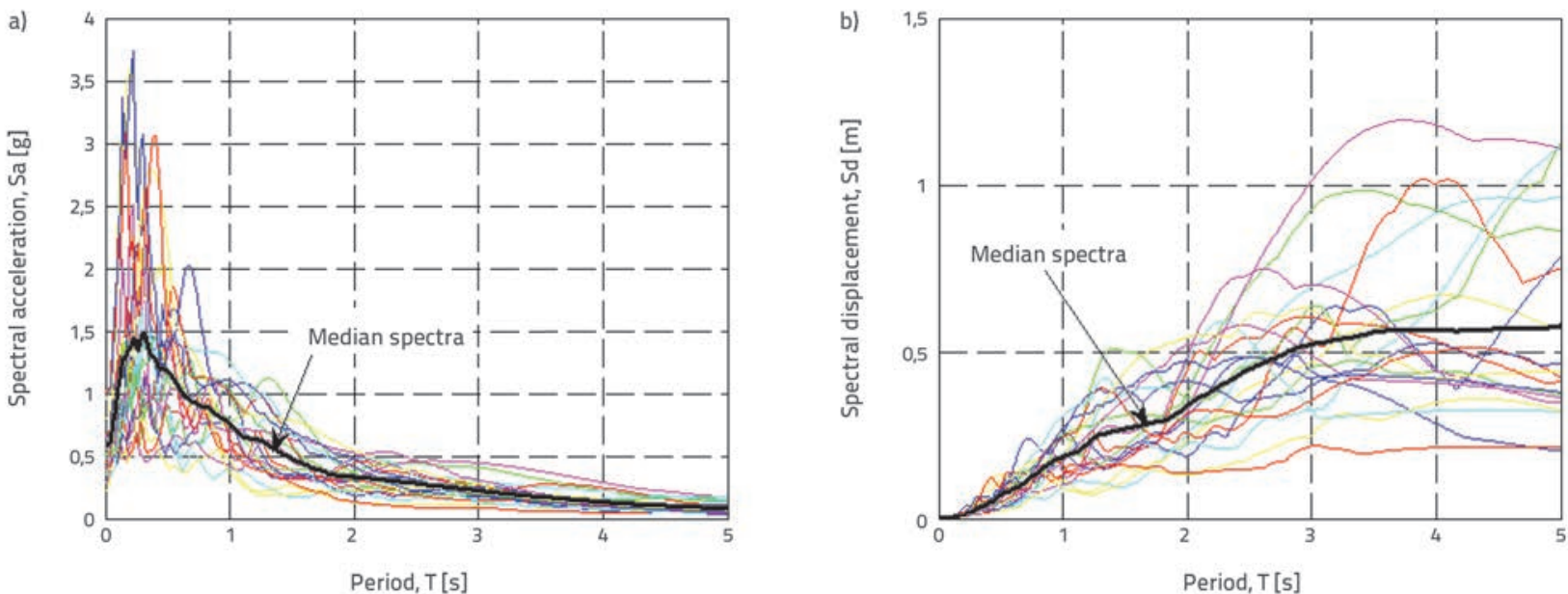

Figure 4. Response spectra for 20 SAC LA10 $(\xi=0.05)$ [16]: a) acceleration spectrum; b) displacement spectrum

Diaphragm thickness was considered a realistic value and then the flexible diaphragm modulus of elasticity $\left(E_{d}\right)$ was calculated using the trial and error method, so that the structure diaphragm flexibility converges to the target value $\left(\gamma_{s}\right)$.

Step D: The analysis of asymmetric structures with flexible diaphragm was conducted:

1. Dynamic analyses were conducted for each mentioned earthquake record, and maximum responses of structures were calculated. Responses similar to those for structures with rigid diaphragm were obtained.

2. Dimensionless parameters were used to evaluate the effect of diaphragm flexibility on seismic demand. For example, Eq.

(5) was used to investigate the effects of diaphragm flexibility on lateral displacement of wall 1 . In this equation, $j$ is the flexibility index.

$\delta_{\text {zid } 1, j_{-} \text {omjer }}=\frac{\delta_{\text {zid1 }, j}}{\delta_{\text {zid } 1 \mathrm{krut}}}$

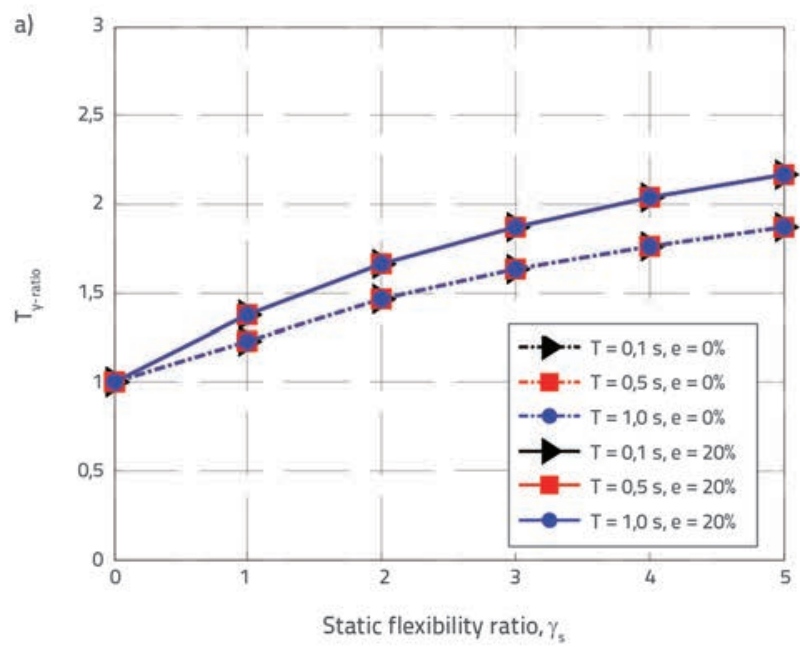

Using the above equation, the response ratio was calculated for each earthquake record and then relationships similar to Eq. (6) were used to calculate the median response ratio for the suite of twenty earthquake records [24]. In this equation, $\mathrm{n}$ is the total number of considered records (20 records).

$\Delta_{\text {zid } 1, j \text { omjer }}=e^{\left(\frac{1}{n} \sum \ln \frac{\delta_{\text {zid } 1, j}}{\delta_{\text {zid } 1 \text { knut }}}\right)}$

\section{Effects of diaphragm flexibility on elastic structures}

In Figure 5a, the ratio of fundamental natural period of structure with flexible diaphragm to that in similar structure with rigid diaphragm $\left(T_{y \text {-ratio }}\right)$ versus flexibility $\left(\gamma_{s}\right)$ are shown for structures with different values of $T$. With an increasing flexibility, translational mode shapes for the structure are dominated by diaphragm deformations and the overall behaviour of the structure becomes more flexible. Consequently, $T_{y \text {-ratio }}$ increases in all cases with an increase in flexibility. As clearly shown in this

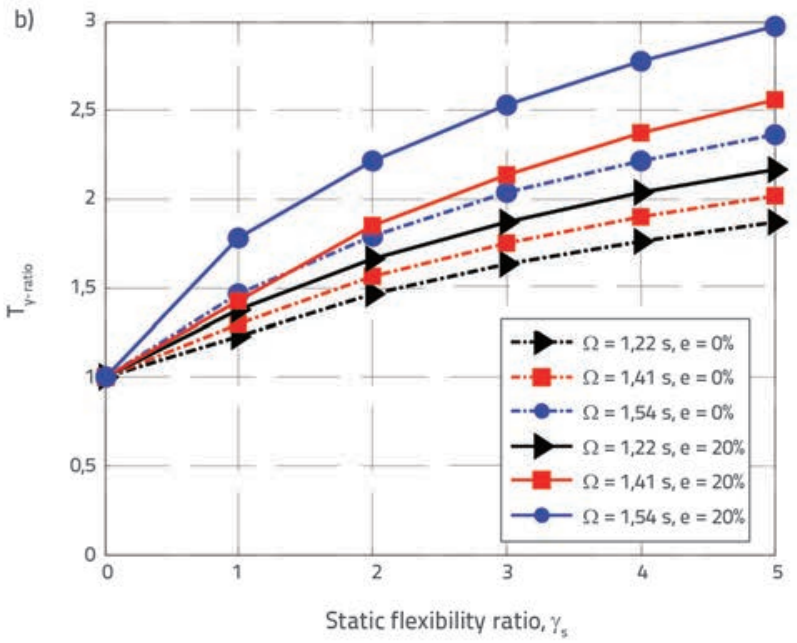

Figure 5. Effect of diaphragm flexibility on fundamental natural period ratio: a) Structures with different $\mathrm{T}(\Omega=1.22)$; b) Structures with different $\Omega$ and $\mathrm{T}=\mathbf{0 . 5 \mathrm { s }}$ 
figure, $T_{y \text {-ratio }}$ does not depend on $T$, and so the curves of structures with different $T$ coincide. Figure 5.b shows the effects of flexibility on $T_{y \text {-ratio }}$ for structures with different values of $\Omega$. As shown in this figure, structures with higher $\Omega$ have a higher $\mathrm{T}_{y \text {-ratio }}$ in both symmetric and asymmetric structures. Also, it is known that structures with more eccentricities, experience a greater $T_{y \text {-ratio }}$ with an increase in flexibility. Generally, $\mathrm{T}_{\mathrm{y} \text {-ratio }}$ has an ascending trend with increasing flexibility.

The median peak relative deformation of walls $\left(\Delta_{\text {wall-ratio }}\right)$ versus flexibility for structures with $\mathrm{T}=0.5 \mathrm{~s}$, e $=0 \%$ and $20 \%$, with different values of $\Omega$, is plotted in Figure 6 . Almost similar trends can be seen in other structures. It is clear that, with an increase in flexibility, end walls on stiff side experience lower displacements compared to those in similar structures with rigid diaphragm. Displacements of these walls are generally constant for $\gamma_{s}>1.0$ so that an increase in flexibility does not have much impact on displacements of the end walls. It should be noted that similar trend was observed for flexible side walls.

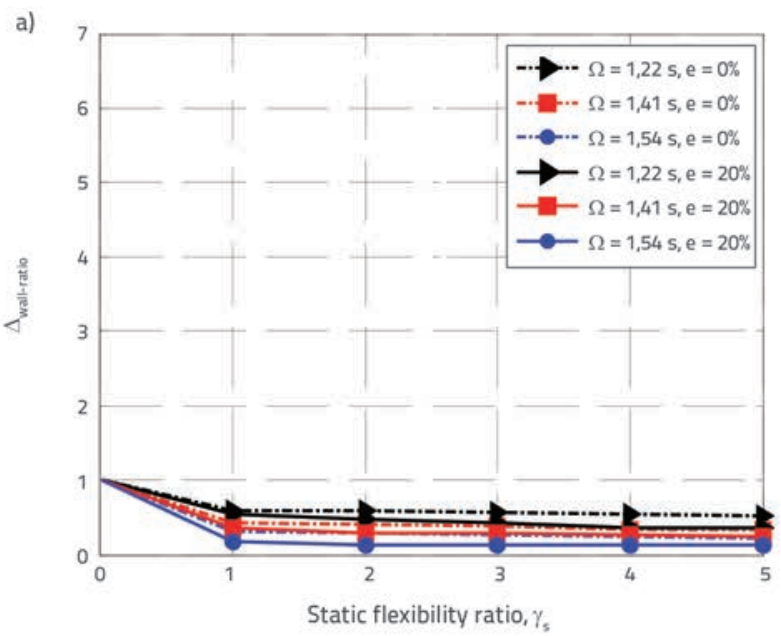

Displacement trends are different in central walls. With an increase in flexibility, higher displacements can be observed in central walls, compared to those in similar structures with rigid diaphragm. Peak values of central wall displacement occur in $\gamma_{s}=1.0$, and so this degree of flexibility can be considered as the most critical flexibility in both symmetric and asymmetric structures. After this critical value, a decreasing or almost constant trend is observed in displacement of the central wall. Also, $\Delta_{\text {wall-ratio }}$ for central walls increases more at higher $\Omega$. Figure 7 shows that median peak total displacement of diaphragms $\left(\Delta_{\text {DIA-ratio }}\right)$ increases with an increase of $\gamma_{s}$ for both sides. At stiff side of structures, higher eccentricities lead to higher $\Delta_{\text {DIA-ratio }}$ compared to symmetric structures, while the reverse behaviour is observed at the flexible side.

Variations of walls base shear $\left(V_{\text {wall-ratio }}\right)$ with $\gamma_{s}$ is shown in Figure 8. It is obvious that static eccentricity has an increasing effect on $V_{\text {wall-ratio }}$ in central walls. In end walls, flexibility leads to the decrement of $V_{\text {wall-ratio }}$.

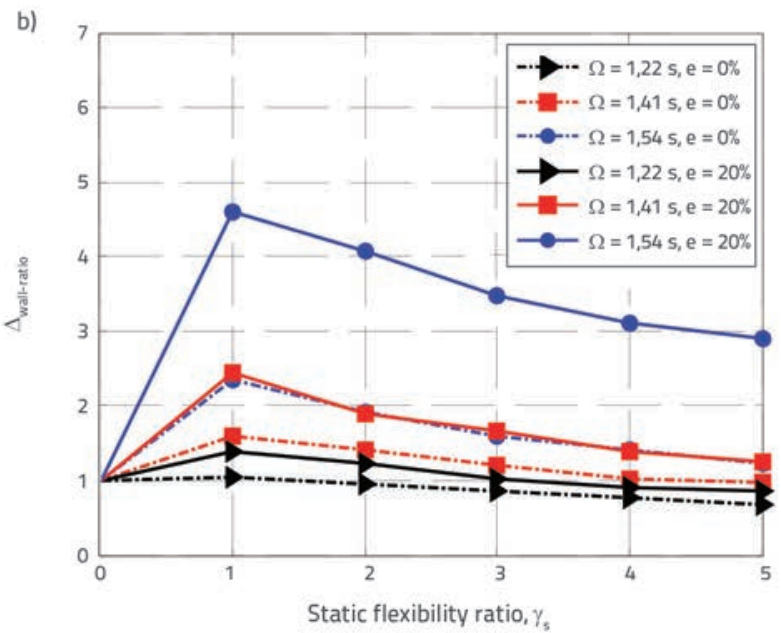

Figure 6. Effect of flexibility on relative displacements of walls in structures with $\mathrm{T}=0.5 \mathrm{~s}$ : a) stiff side walls; b) central walls

a)

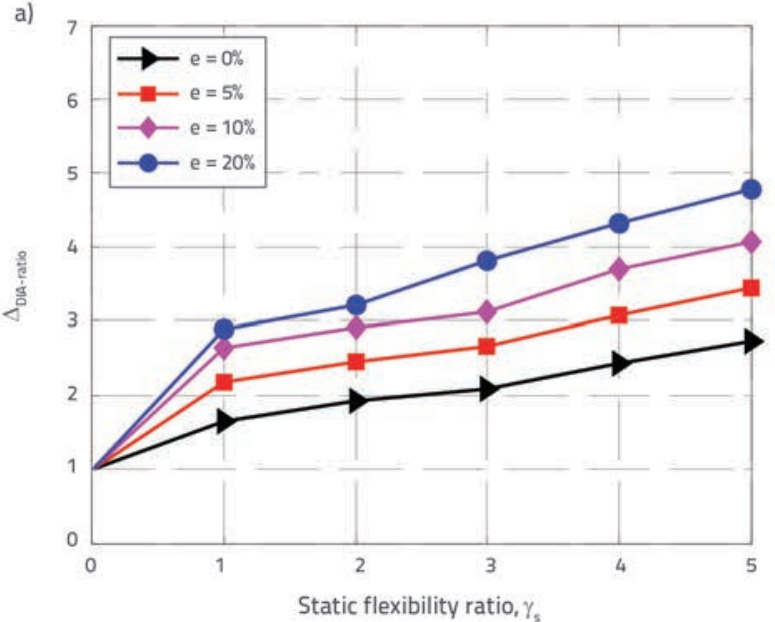

b)

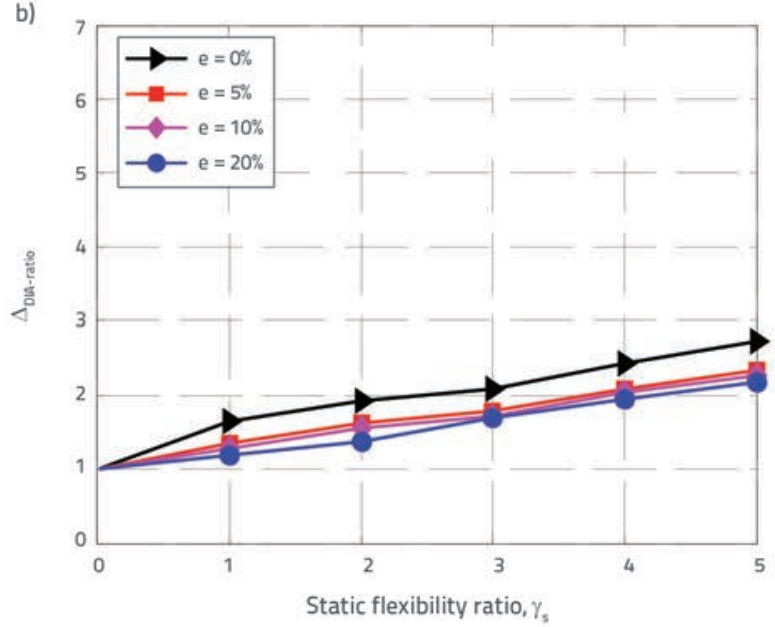

Figure 7. Effect of $\gamma_{s}$ on $\Delta_{D / A-\text {-ratio }}$ in structures ( $(T=1.0 \mathrm{~s}, \Omega=1.22$ ): a) Stiff side diaphragms; b) Flexible side diaphragms 

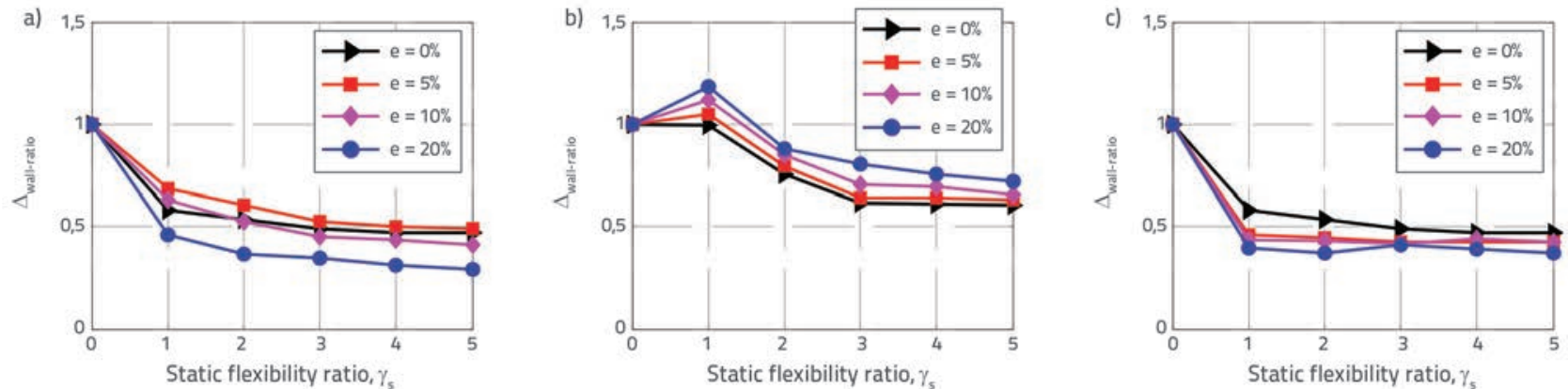

Figure 8. Effect of flexibility on base-shear of walls for structures with ( $T=1.0 \mathrm{~s}, \Omega=1.22$ ): a) stiff side walls; b) central walls; c) flexible side wall

\section{Effects of diaphragm flexibility on inelastic structures}

The yield strength of each lateral element $\left(F_{y i}\right)$ for each earthquake was obtained by dividing the maximum force demand of the element from elastic analysis $\left(F_{e j}\right)$ by response reduction factor $(R)$. Just like in previous section, the diaphragm was considered to behave in an elastic range. Nonlinear analysis was conducted only for structures with $\Omega=1.22$ and $\mathrm{R}=1$ (elastic), 2, 4, 6 .

\subsection{Effects of flexibility on deformation of walls in nonlinear structures}

Figure 9 shows the effect of $\gamma_{\mathrm{s}}$ on $\Delta_{\text {wall-ratio }}$ for symmetric structures with different $T$ and $R$. Almost similar trends can be observed in other structures. Evidently, end walls of inelastic structures, unlike elastic structures, experience a greater displacement compared to structures with rigid diaphragm. In structures with smaller $T$, higher $\gamma_{s}$ leads to a greater displacement of all walls. The effect of flexibility on $\Delta_{\text {wall }}$ in symmetric structures with $T$ $=0,5 \mathrm{~s}$, and different response reduction factors, are shown in Figure 10. As can be seen, an increase in $R$ leads to higher displacement of walls. Also, with an increase in flexibility, displacements of walls in nonlinear structures generally have an ascending trend, unlike elastic structures.

Variations of $\Delta_{\text {wall-ratio }}$ versus flexibility for asymmetric structures are shown in Figure 11. As can clearly be seen in Figure 11a, stiff side walls of nonlinear structures generally experience a greater displacement with an increase in flexibility, compared to those in similar structures with rigid diaphragm. Also, at higher eccentricity, stiff side walls generally experience a greater $\Delta_{\text {wall-ratio }}$ than those in symmetric structures. As shown in Figure 11b, an increase in $\gamma_{s}$ leads to a nearly 50 percent increase in central wall displacement compared to those in similar structures with rigid diaphragm. Also the static eccentricity does not have a significant impact on the displacement of central walls. As shown in Figure 11c, flexibility does not have a great impact on displacement of flexible side walls of inelastic structures.
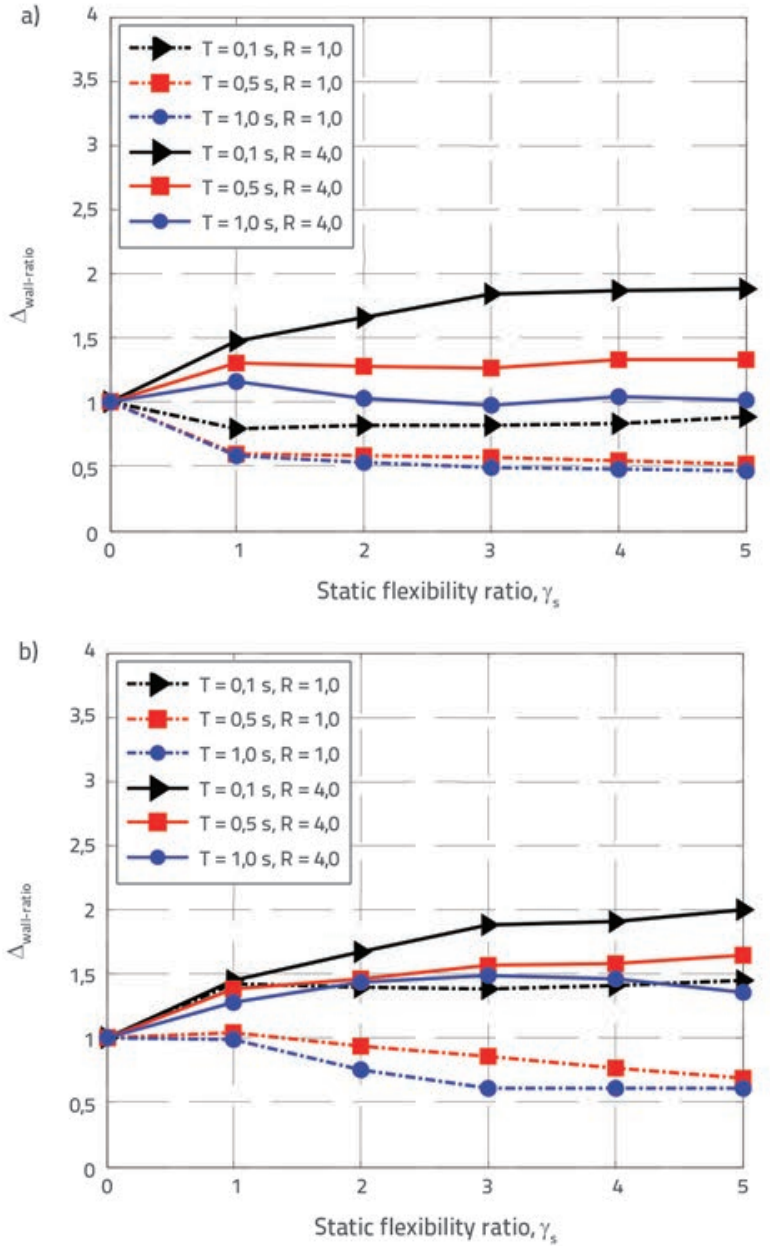

Figure 9. Effect of diaphragm flexibility on wall displacement ratio $\Omega$ = 1.22: a) End walls; b) Central walls

\subsection{Effects of diaphragm flexibility on diaphragm deformation in nonlinear structures}

The effects of diaphragm flexibility on $\Delta_{\text {DIA-ratio }}$ in asymmetric structures with different response reduction factors are depicted in Figure 12. As can be observed, an increase in $R$ leads to lower $\Delta_{\text {DIA-ratio }}$ of both diaphragms. Also, $\Delta_{\text {DIA-ratio }}$ 
a)

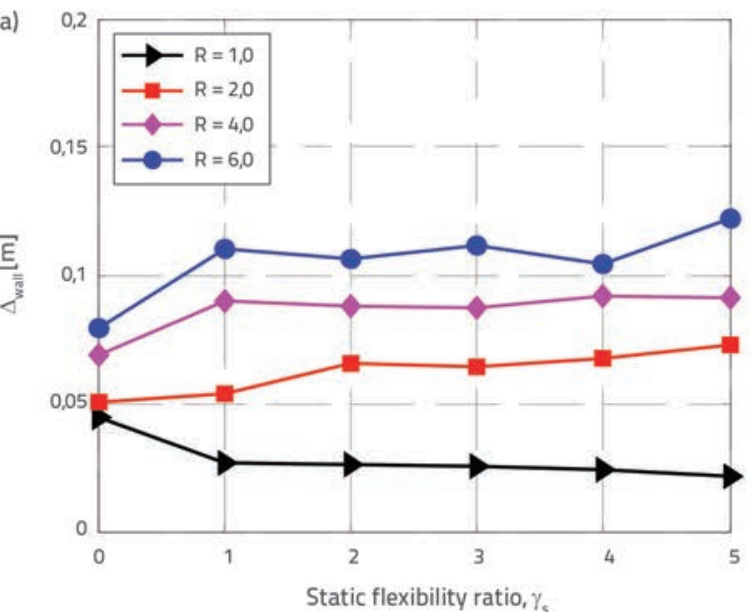

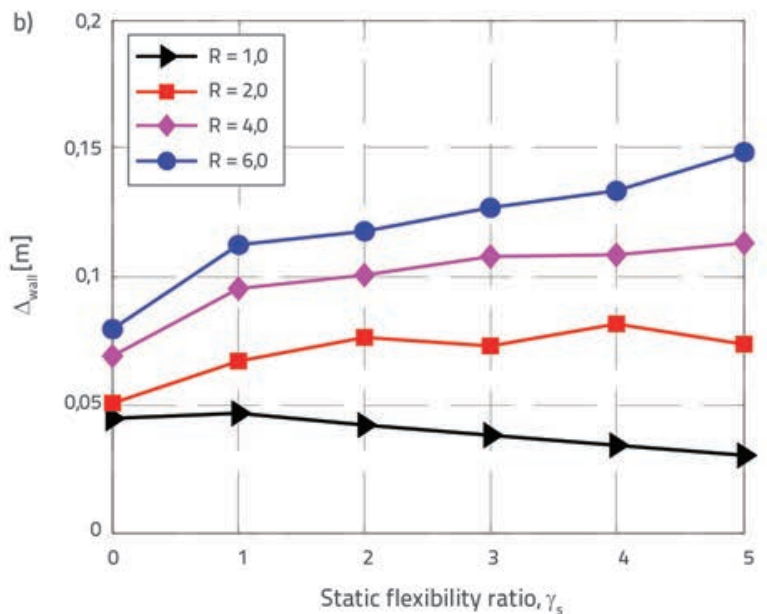

Figure 10. Effect of flexibility on displacement of walls in structures with ( $T=1.0 \mathrm{~s}, \mathrm{e}=0 \%, \Omega=1.22$ ): a) End walls; b) Central walls
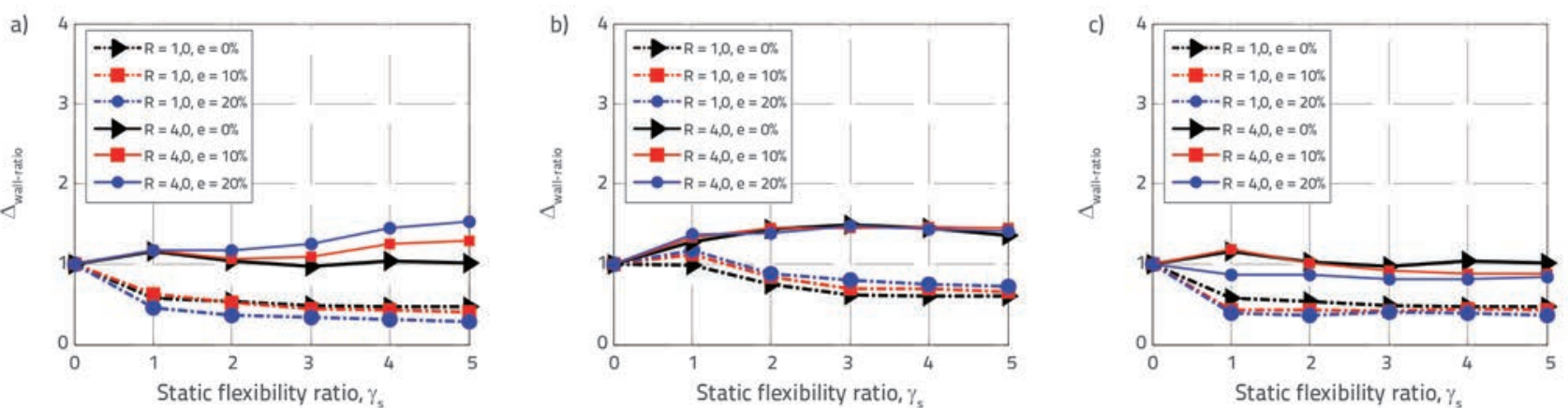

Figure 11. Effect of flexibility on walls displacement ratio in nonlinear structures with ( $T=0.5 \mathrm{~s}, \Omega=1.22$ ): a) Stiff side walls; b) Central walls; c) Flexible side walls
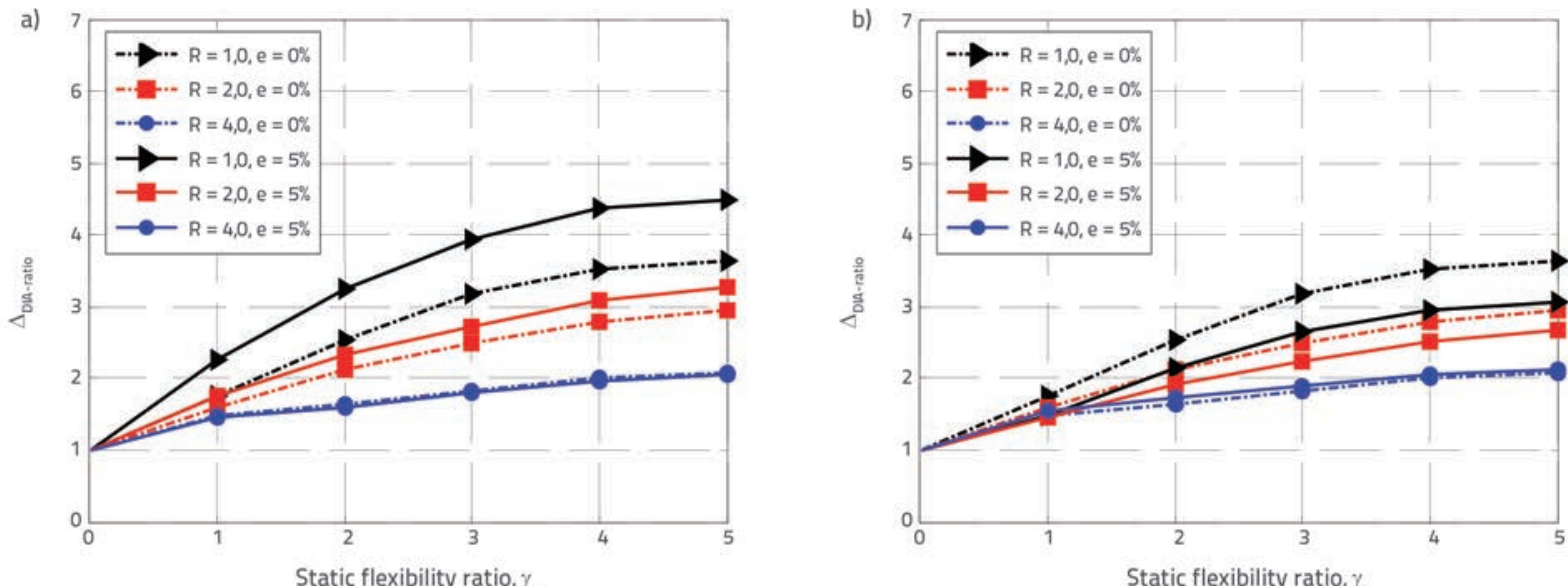

Figure 12. Effect of flexibility on displacement of diaphragms in structures with ( $T=0.5 \mathrm{~s}, \Omega=1.22$ ): a) Stiff side diaphragms; b) Flexible side diaphragms

always increases with an increase in flexibility, but the increasing slope gradually reduces.

Figure 13 exhibits the effects of diaphragm flexibility on $\Delta_{\text {DIA- }}$ ratio for structures with different values of static eccentricity.
A comparison between figures 7 and 13 clearly reveals that sensitivity of $\Delta_{\text {DIA-ratio }}$ to static eccentricity is reduced in nonlinear structures, and the higher values of $R$ lead to a decrease in static eccentricity effects. 

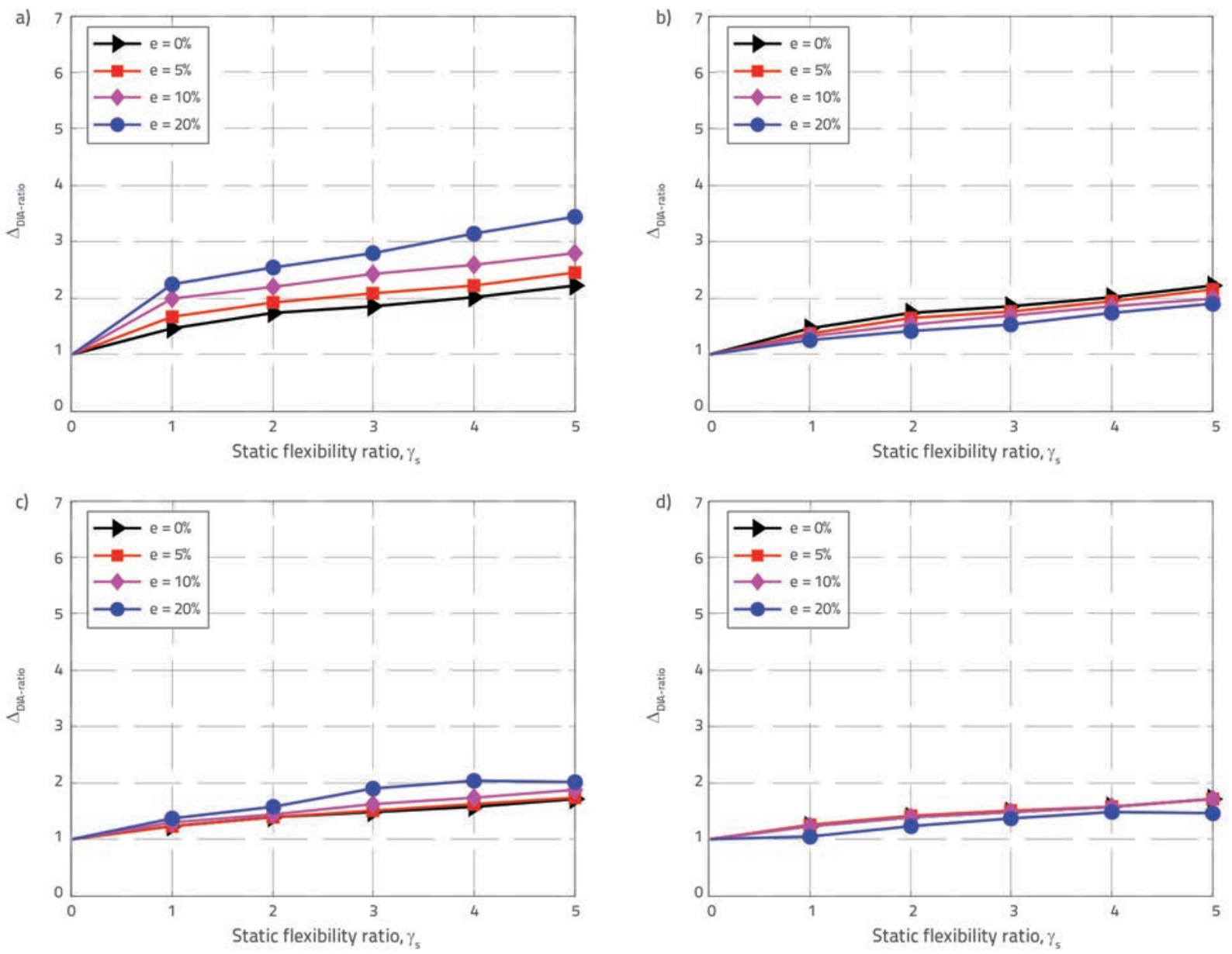

Figure 13. Effect of flexibility on displacement of diaphragms in structures with $T=1.0 \mathrm{~s}$ : a) Stiff side diaphragms, $R=2 ;$ b) Flexible side diaphragms, $R=2 ; c$ ) Stiff side diaphragms, $R=6$; d) Flexible side diaphragms, $R=6$

\section{Conclusions}

The effects of diaphragm flexibility on seismic response of asymmetric-plan structures, with different uncoupled natural periods, stiffness eccentricities and torsional to lateral frequency ratios, are investigated in this paper by a comprehensive parametric study. The behaviour of structures under one-directional seismic load is investigated in both linear and nonlinear ranges. The results reveal that:

- Generally, in all structures with a high diaphragm flexibility, the fundamental natural period of structures was higher relative to similar structures with rigid diaphragm. In asymmetric-plan structures, especially in those with higher eccentricities and/or torsional to lateral frequency ratios, a further increase in period was observed compared to similar symmetric structures. This increase in the period, depending on the natural period of the initial structure with rigid diaphragm and the soil type, can cause an increase in spectral acceleration (ascending branch), decrease in spectral acceleration (descending branch), or no change in spectral acceleration (fixed branch) in structures with flexible diaphragm.
- With an increase in flexibility, the distribution of lateral forces between LLREs is more based on tributary area. This change in behaviour of structures leads to higher displacements of central walls compared to those in similar structures with rigid diaphragm. In the asymmetric-plan structures with higher eccentricities and/or torsional to lateral frequencies, more critical displacement demands were found for central walls.

- End walls of inelastic structures with flexible diaphragm, unlike elastic structures, experienced more deformations compared to structures with rigid diaphragm. The static eccentricity did not have a significant impact on the displacement of central walls. In nonlinear structures, unlike in linear structures, critical diaphragm flexibility point did not exist.

- Generally, diaphragm displacement demands in nonlinear structures were less sensitive to eccentricity compared to linear structures. Higher R led to lower $\Delta_{\text {DIA-ratio }}$ on both stiff and flexible side diaphragms.

- In this study, one-storey models were used to study the effects of diaphragm flexibility. According to previous studies $[25,26]$, it is expected that these results could be generalized to low-rise and regular height multi-storey structures. 


\section{REFERENCES}

[1] De-La-Colina, J.: In-Plan Floor Flexibility Effects on Torsionally Unbalanced Systems, Earthquake Engineering and Structural Dynamics, 28 (1999), pp. 1705-1715, https://doi.org/10.1002/ (SICI)1096-9845(199912)28:12<1705::AID-EQE873>3.0.CO;2-5

[2] Farrow, K.T., Fleischman, R.B.: Dynamic Behaviour of Perimeter Lateral-System Structures with Flexible Diaphragms, Earthquake Engineering and Structural Dynamics, 30 (2001), pp. 745-763, https://doi.org/10.1002/eqe.36.

[3] Tena-Colunga, A., Chinchilla-Portillo, K.L., Juárez-Luna, G.: Assessment of the diaphragm condition for floor systems used in urban buildings, Engineering Structures, 93 (2015), pp. 70-84.

[4] Eivani, H., Sarvghad Moghadam, A., Aziminejad, A., Nekooei, M.: Seismic Response of Plan-Asymmetric Structures with Diaphragm Flexibility, Shock and Vibration, pp. 1-18, 2018, https://doi.org/10.1155/2018/4149212

[5] Lee, H.J., Aschheim, M.A., Kuchma, D.: Interstorey Drift Estimates for Low-Rise Flexible Diaphragm Structures, Engineering Structures, 29 (2007), pp. 1375-1397, https://doi.org/10.1016/j. engstruct.2006.08.021

[6] Ahmadi, M., Abu Bakar, S., Satih Abbas, H.: Investigation into diaphragm flexibility using shear wall, GRAĐEVINAR, 66 (2014) 9, pp. 831-836, https://doi.org/10.14256/JCE.1049.2014

[7] Morić, D.: Designing Seismic Response of Buildings without Rigid Floors, GRAĐEVINAR, 52 (2000) 11, pp. 673-681.

[8] Jain, S.K., Jennings, P.C.: Analytical Models for Low-Rise Buildings with Flexible Floor Diaphragms, Earthquake Engineering and Structural Dynamics, 13 (1985), pp. 225-241, https://doi. org/10.1002/eqe.4290130207

[9] Moon, S.K., Lee, D.G.: Effects of In-plane Floor Slab Flexibility on the Seismic Behaviour of Building Structures, Engineering Structures, 16 (1994), pp. 129-144, https://doi.org/10.1016/01410296(94)90038-8

[10] Tremblay, R., Stiemer, S.F.: Seismic Behaviour of Single-Storey Steel Structures with a Flexible Roof Diaphragm, Canadian Journal Civil Engineering, 23 (1996), pp. 49-62, https://doi.org/10.1139/ 196-006

[11] Kim, S.C., White, D.W.: Nonlinear Analysis of a One-Storey LowRise Masonry Building with a Flexible Diaphragm Subjected to Seismic Excitation, Engineering Structures, 26 (2004), pp. 20532067, https://doi.org/10.1016/j.engstruct.2004.06.008

[12] Valipour, H.R., Foster, S.J.: Nonlinear Analysis of 3D Reinforced Concrete Frames: Effect of Section Torsion on the Global Response, Structural Engineering and Mechanics, 36 (2010), pp. 421-445, https://doi.org/10.12989/sem.2010.36.4.421

[13] Koren, D., Kilar, V.: Torsion of seismically isolated structures of irregular plan, GRAĐEVINAR, 60 (2008) 2, pp. 99-108.
[14] Tena-Colunga, A., Abrams, D.: Seismic Behaviour of Structures with Flexible Diaphragms, Journal of Structural Engineering, 122 (1996), pp. 439-445, https://doi.org/10.1061/(ASCE)07339445(1996)122:4(439)

[15] Kunnath, S., Panahshahi, N., Reinhorn, A.: Seismic Response of RC Buildings with Inelastic Floor Diaphragms, Journal of Structural Engineering, 117 (1991), pp. 1218-1237, https://doi.org/10.1061/ (ASCE)0733-9445(1991)117:4(1218)

[16] Eivani, H.: The effects of semi-rigid diaphragm on the seismic response of torsional buildings with reinforced concrete shear walls. Ph.D. Dissertation in persion, Department of Civil Engineering, Science and Research Branch, Islamic Azad University, Tehran, Iran, 2018.

[17] American Society of Civil Engineers (ASCE): Minimum design loads for buildings and other structures (ASCE/SEI 7-10), Virginia, USA. 2010.

[18] Aschheim, M.: Seismic design based on the yield displacement, Earthquake Spectra, 18 (2002), pp. 581-600, https://doi. org/10.1193/1.1516754

[19] Aziminejad, A., Moghadam, A.S.: Fragility-based performance evaluation of asymmetric single-storey buildings in near field and far field earthquakes, Journal of Earthquake Engineering, 14 (2010), pp. 789-816, https://doi.org/10.1080/13632460902837728

[20] Paulay, T:: Some design principles relevant to torsional phenomena in ductile buildings, Journal of Earthquake Engineering, 5 (2001), pp. 273-308, https://doi.org/10.1080/13632460109350395

[21] Myslimaj, B., Tso, W.K.: A strength distribution criterion for minimizing torsional response of asymmetric wall-type systems, Earthquake Engineering and Structural Dynamics, 31 (2002), pp. 99-120, https://doi.org/10.1002/eqe.100

[22] OpenSees Open System for Earthquake Engineering Simulation; Earthquake Engineering Research Center (PEER), California, USA, http://opensees.berkeley.edu, 2017.

[23] Building and Housing Research Center: Iranian code of practice for seismic resistant design of buildings (Standard No. 2800), Tehran, Iran, 2014.

[24] Luco, N.: Probabilistic seismic demand analysis, SMRF connection fractures, and near-source effects. Ph.D. Dissertation, Department of Civil and Environmental Engineering, Stanford University, Stanford, CA, 2002

[25] De la Llera, J.C., Chopra, A.K.: Accidental and Natural Torsion in Earthquake Response and Design of Buildings, Report of the Earthquake Engineering Research Center, Report No 94/07, University of California, Berkeley, California, USA, June 1994.

[26] Nakamura, Y., Derakhshan, H., Magenes, G., Griffith, M.C.: Influence of Diaphragm Flexibility on Seismic Response of Unreinforced Masonry Buildings, Journal of Earthquake Engineering, pp. 1-26, 2016. 